\title{
The Relationship between Perceived Supervisor Support, Perceived Organizational Support, Organizational Commitment and Employee Turnover Intention
}

\author{
Anneswary Kalidass ${ }^{1} \&$ Arsiah Bahron ${ }^{1}$ \\ ${ }^{1}$ Faculty of Business, Economics and Accountancy, Universiti Malaysia Sabah, Malaysia \\ Correspondence: Arsiah Bahron, Faculty of Business, Economics and Accountancy, Universiti Malaysia Sabah, \\ Jalan UMS, 88400 Kota Kinabalu, Sabah, Malaysia. E-mail: bharsiah@ums.edu.my
}

Received: July 23, 2015

Accepted: August 7, 2015

Online Published: September 16, 2015

doi:10.5430/ijba.v6n5p82

URL: http://dx.doi.org/10.5430/ijba.v6n5p82

\begin{abstract}
This study aims to investigate the influence of perceived supervisor support, perceived organizational support and organizational commitment towards employees' turnover intention. It has been discovered through previous literature that perceived supervisor support, perceived organizational support and organizational commitment are associated with employees' turnover intention. This study collected data from 260 respondents selected from eight three-star hotels in Kota Kinabalu area. Each of the independent variables - perceived supervisor support, perceived organizational support and organizational commitment were regressed towards employees' turnover intention (dependent variable). The findings show that there is a significant relationship between perceived supervisor support, perceived organizational support and organizational commitment towards employees' turnover intention. This study suggests that more attention shall be given from the hotel management towards the employees to reduce the turnover intention. Apart from that, the study was able to gather some useful information for the hoteliers and managers pertaining to the respondents' profile and what exactly the employees expect from the organization.
\end{abstract}

Keywords: perceived organizational support, perceived supervisor support, organizational commitment, employees' turnover intention

\section{Introduction}

Hotel industry is among the major contributors to the development of Tourism Industry in Malaysia. The hotels organization usually observe high turnover (Davidson, Timo \& Wang, 2009). The standard employee turnover rate was reported higher as 66\% per annum for the particular year of 1998-1999 (Malaysian Association of Hotels, 2000). Hotels are experiencing employee scarcity problems that are caused by high turnover (Lee \& Choon, 2000). When employees have experience lack of support, the employees are probable to show extraction attitudes which include the intentions to disappear from the organization (Guzzo et al., 1994; Wayne et al., 1997). It is supported by Guzel et al., (2011), an organization that provide such support for its employees improves employees' loyalty within the organization at the same time as reducing negative feelings and thoughts about the concerning organization.

The Perceived Supervisor Support (PSS), Perceived Organizational Support (POS) and Organizational Commitment are the main backbone for the hotel industry to reduce the turnover intention among their employees. PSS and POS are valuable factor that have the potential to create strategic ways for turnover management and supervisors acting encouraging seem to be normally excellent for reducing the turnover intentions among employees (Tuzun \& Kalemci, 2011). Supportive organization causes employees to feel obligation on adopting some additional roles such as helping other employees working in the same organization (Shanock \& Eisenberger, 2006). Furthermore, employees that have lower experience of organizational commitment are probable leaving the organization (Huselid \& Day, 1991). The staff turnover has a largely negative effect in a service business such as hospitality service operations (Lashley, 2001). Therefore this study intends to observe the influence of PSS, POS and organizational commitment towards employee's intention to leave the organization. The scope of this study was focused on private sector employees that selected from the hotel industry in Kota Kinabalu area with the aim to gain precious local data. Even though, there are tremendous developments of hotels in Malaysia, it seems that the tribulations of employees' turnover are widespread and remain the highest in the hospitality industry (Hemdi \& Nasrudin, 2006). 


\subsection{PSS and Turnover Intention}

According to Maertz et al., (2007), employees turnover is influenced through support from the supervisor which also affecting the employees perception and attitudes relates to the organization itself. It is agreed that employees has differentiate its relationship between the supervisor and the organizational entity to be part of them (Becker, 1992; Dirks \& Ferrin, 2002; Reichers, 1985) but by responding towards the PSS, any result of responsibility should be generally towards the supervisor rather than the organization (Hoffman \& Morgeson, 1999). A study conducted by Maertz and Griffeth (2004) demonstrated that supervisor attachments have separate effects on turnover cognitions, separately from attachments and attitudes related to the organization itself. In return, the employee tends to respond their actions towards the target from which it benefits them (Hoffman \& Morgeson, 1999).

Therefore, the turnover intentions among employees should consider the potential relationship between employees and the supervisor which directly affecting the employees' turnover decision. By increasing the PSS and level of commitment, the organization can reduce the turnover intentions of their employees (Newman, Thanacoody \& Hui, 2012). PSS is crucial to retain employees in the organization (Gentry et al., 2006). A study by Eisenberger et al., (2002), argued that there is no evidence showing the relationship between PSS and turnover intentions, however, PSS had significant relationship with turnover intentions only when the relationship was mediated by POS. On the contrary, by increasing the PSS could potentially react negatively towards the employees as well because of the relatively frequent interactions between supervisors and employees, the supervisors have become the primary focus and main reference for the employees most of the time (Maertz et al., 2007).

\subsection{POS and Turnover Intention}

One of the positive organizational aspects is the perceived organizational support (Mowday, 1998). According to Eisenberger et al., (1986), POS is defined as the social exchange relationship that results from exchange between an employee and the employing organization. Individual with high POS would be less likely to seek out and accept jobs in alternative organizations (Tuzun \& Kalemci, 2011; Eisenberger et al., 1990). The study is supported by Loi et al. (2006), suggested that by enhancing POS would lower employees' intentions to leave the organization. Apart from that, focusing on the concept of POS would be the key predictor of turnover intentions (Maertz et al., 2007). When employees believe that they are being supported by the employers, the employees reciprocate by having lower turnover intentions (Cropanzano et al., 1997). POS also have positive impact on employee attitudes and behaviors mainly because POS creates a sense of obligation within the employees to repay the organization through the organizational support theory (Eisenberger et al., 1986; Eisenberger et al., 1990). POS can influence employees' felt commitment to care about the organization and to help it reach its goals, and this obligation can exert pervasive effects on turnover intention (Nasrin Arshadi, 2011).

POS is claimed to have relationship towards the employees' turnover intention in the organization. A study by Ghiselli et al., (2001), claimed that the turnover intentions are likely to be influence by the dimensions of POS, which POS was also found to have a direct influence on employees' turnover intention (Nasrin Arshadi, 2011). In a study by Talat Islam (2013), POS was found to influence turnover intentions negatively because when the employees experience support from organizations, the employees respond it by showing more loyalty and changing their intentions to leave the organization. The study is supported by Wayne et al., (1997), argued that POS and turnover intentions were found to have a negative relationship.

\subsection{Organizational Commitment and Turnover Intention}

Organizational commitment is defined as the relative strength of an individual's recognition with, and participation in, an organization (Mowday, Steers \& Porter, 1979). Employees that are highly loyal are less likely to leave the organization (Meyer et al., 2002). In regards with the employees' turnover intention, organizational commitment has always been a significant subject in the organization that associates to employees' turnover intention (Allen \& Meyer, 1993). According to Tett and Meyer (1993), organizational commitment contributes exclusively towards the turnover intention cognitions. Griffeth, Horn and Gaertner (2000) pointed out that to predict turnover among employees, the organizational commitment would be a better indicator to suppress the findings of turnover intentions. The findings by Kanwar, Singh and Kodwani (2012) prove that a fulfilled employee will demonstrate greater responsibility towards the organization. More specifically, it relates to employees' feelings which they are more likely to become committed to an organization when they sense that the organizations is faithful to them too (Fuller, Barnett, Hester \& Relyea, 2003). There are three types of organizational commitment dimensions which are the affective commitment, continuance commitment and normative commitment (Allen \& Meyer, 1990; Allen \& Meyer, 1991). A study conducted by Wong, Ngo and Wong (2001) argued that affective commitment is found to be both significantly and negatively related to turnover intention. Past researchers has found out that the organizational 
commitment have significant correlation with the employees' turnover intentions (Ben-Bakr et al., 1994). According to Meyer et al., (1993), a number of studies have definite that the essential role of organizational commitment as the main antecedent of turnover intentions, however, there were also studies that found the negative and significant relationship between organizational commitment and turnover intentions.

\section{Research Method}

The location of the study is in Kota Kinabalu which covers all the three-star hotels that registered under Malaysian Association of Hotel (MAH). The eight hotels are the ordinary member of MAH and well-known hotels for most of the people in Kota Kinabalu. There are eight three-star hotels were chosen which have approximately 800 employees. The total population for each hotel compromise of 60 to 150 employees. In order to calculate the necessary minimum sample size need, the margin error is $5 \%$ with $95 \%$ of confidence level and the $50 \%$ of response distribution. The number of population is 800 thus the sample size need is 260 respondents. The target population is the hotel employees from middle management, lower management and the supporting staff.

The number of three-star hotel in Kota Kinabalu city is 20 hotels. The sampling frame conducted through the MAH data website which consists of registered three-star hotels with complete contact information. The total of three-star hotels that registered under MAH is eight hotels. It is more reliable to choose hotels that are registered under MAH which the hotels is well protected by this association. The employees will be more loyal to the hotels that registered under MAH association that brings benefits to the management. The population is divided using stratified sampling method to get the sample size from each of the hotel. Thus, the results show that $33 \%$ from each of the hotel's population is needed for the research. Every unit in the stratum has same chance if being selected. The eight hotels in Kota Kinabalu that have different population size are dividing using sampling fraction to get smaller sample size. The three-star hotels are Cititel Express (275 rooms), Gaya Centre Hotel (260 rooms), Imperial Boutec Hotel (93 rooms), Jesselton Hotel (32 rooms), Klagan Hotel (208 rooms), Likas Square Condotel (77 rooms), Sabah Oriental Hotel (200 rooms) and Shangri-La Hotel (121 rooms). Since the number of population is approximately 800 employees, the smaller sample of 260 is needed.

For this study, about 260 questionnaires were distributed among the hotel employees from the middle level management to low level employees in eight hotels. Convenience sampling method was used in this study and the questionnaire was distributed among the hotel employees starting from middle management and below of randomly selected hotels. The questionnaires distributed to the target participants and gather it through the Human Resource Department in every each of the selected hotels.

The research framework for this study is depicted in Figure 1. The theoretical framework is partly a replication from the past study conducted by Maertz Jr et al., (2007), Stinglhamber \& Vandenberghe (2003), Deconinck \& Johnson (2009), Eisenberger et al., (1997) and Nasrin Arshadi (2011).

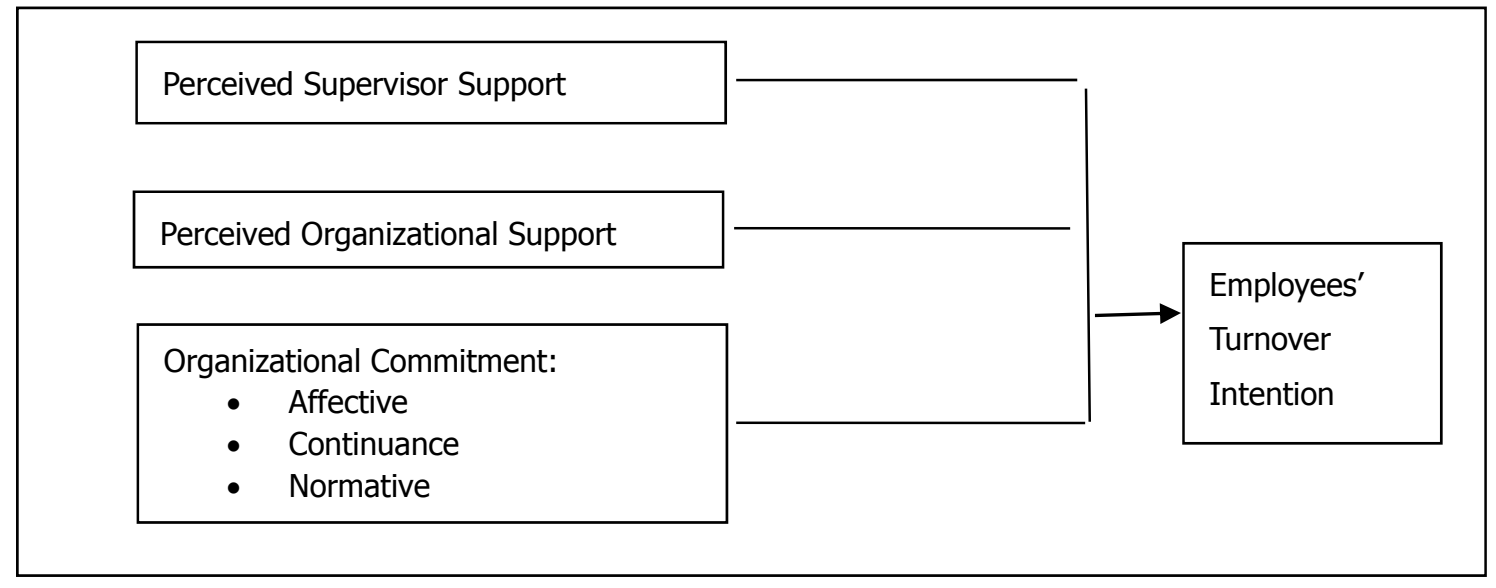

Figure 1. Research framework

According to Ito and Brotheridge (2005), supervisor support could assist employees to meet their aims for continuous development and for becoming valued associate of the organization. Supervisor acting encouraging and endorsing subordinates seems to be normally better for retention (Maertz Jr et al., 2007). According to Maertz et al., 
(2007), supervisor connections have different possessions towards turnover cognitions, other than the attachments and approaches related to the organization itself. These theoretical findings all strongly propose that PSS should cause attachments straightforwardly to the supervisor, which should influence turnover cognitions directly.

Hypothesis 1: PSS will have a significant relationship with employees' turnover intentions.

In a study by Tekleab et al., (2005) claimed POS lead to felt responsibility owed to the organization out of faithfulness to a reciprocity norm. The relationships of POS to behavioral intentions to leave have been assessed (Wayne et al., 1997). Thus, the past findings suggest that POS should directly affect the turnover intentions in order to cope with the result of turnover cognitions.

Hypothesis 2: POS will have a significance relationship with employees' turnover intentions.

Past research have indicated affective commitment as the strength of an individual's recognition with and participation in a particular organization (Porter et al., 1974), continuance commitment occurs from the recognition that one would mislay valued "side bets" upon leaving the organization, while normative commitment shown the readiness to stay with the organization due to wisdom of moral obligation (Wiener, 1982). The three forms of organizational commitment which are affective commitment, continuance commitment and normative commitment indicated that every aspect of its findings is related to turnover intention within the organization.

Hypothesis 3: Organizational commitment will have a significant relationship with employees' turnonver intention.

Hypothesis 3a: Affective commitment will have a significant relationship with employees' turnover intentions.

Hypothesis 3b: Normative commitment will have a significant relationship with employees' turnover intentions.

Hypothesis 3c: Continuance commitment will have a significant relationship with employees' turnover intentions.

The PSS variable was measured with the three items scales, using two revised items similar to those used by Eisenberger et al., (2002) and 8 items POS scale by Eisenberger et al., (1986). The third item create would superlative reflect the outstanding six items (Dawley, Houghton \& Bucklew, 2010). A sample item is, 'I am very satisfied with my supervisor'. The reliability for this scale was 0.94. Participants responded on 5-point Likert-type scale from "1" (Strongly Disagree) to "5" (Strongly Agree). It is easier for the respondents to understand the question and respond more accurate answer. In order to answer an item, employees are requested to select a choice which best matched their opinion and conforming the level of agreement to each of the statement.

The POS part was measured with the same 8 high-loading items SPOS used to assess PSS (Eisenberger et al., 1986). The past research shows the reliability coefficients (Cronbach's Alpha) for the SPOS were 0.89 (Eisenberger et al., 1986). The 5-point Likert-type scale limits the respondent's bias in terms of the phenomenon of inner tendency in the answer ratings while still providing enough answering options. A sample item is, 'The organization values my contribution to its well-being'.

Organizational commitment was measured with the 24-items scale taken from Meyer and Allen (1997). There were three dimensions of organizational commitment which are affective commitment, continuance commitment and normative commitment. Every each of the forms consists of 8-items. Participants responded on 5-point Likert-type scale from 1" (Strongly Disagree) to "5" (Strongly Agree). The reliability for affective commitment sample item shows Cronbach's Alpha of 0.87, continuance commitment with 0.75 and normative commitment is 0.79 (Allen \& Meyer, 1990). A sample item for affective commitment is, 'I would be very happy to spend the rest of my career with this organization'. The sample item for continuance commitment is, 'I am not afraid of what might happen if I quit my job without having another one lined up'. For normative commitment, the sample item is, 'I think that people these days move from company to company too often'.

Turnover intentions were measured with three items adapted from Vigoda-Gadot and Kupin (2005), which it is reported to have an alpha of 0.84 for the private sector organizations. The response scale ranged from "1" (Strongly Disagree) to "5" (Strongly Agree). The three sample items are, 'I often think about quitting', 'I will probably not stay with this organization for much longer', and 'Lately, I have taken an interest in job offers in the newspaper'. 


\section{Results}

The relationship between PSS and Turnover Intention - The first hypothesis (H1) examined whether there is a significant relationship between PSS and turnover intention. Results indicated that $16.1 \%$ variances in turnover intention can be explained by PSS $\left(\mathrm{R}^{2}=16.1, \mathrm{p}<0.01\right)$. There is a negative relationship between PSS and turnover intention as indicated by the value of $\beta=-.402(\mathrm{p}<0.01)$. Therefore, $\mathrm{H} 1$ is supported.

Table 1. PSS and turnover intention

\begin{tabular}{llc}
\hline Dependent Variable & Independent Variable & $\begin{array}{c}\text { Std. Coefficient } \\
\text { Beta }(\beta)\end{array}$ \\
\hline Turnover Intention & Perceived supervisor support & $-0.402^{* *}$ \\
\hline & $\mathrm{R}^{2}$ & 0.161 \\
& Adjust $\mathrm{R}^{2}$ & 0.158 \\
& Sig. F & $49.59^{* *}$ \\
\hline
\end{tabular}

Note: Significant levels: ${ }^{* *} \mathrm{p}<0.01$

The relationship between POS and Turnover Intention - The second hypothesis (H2) examined whether there is a significant relationship between POS and turnover intention. Results indicated that 33\% variances in turnover intention can be explained by PSS $\left(\mathrm{R}^{2}=33.0, \mathrm{p}<0.01\right)$. For the second hypothesis $(\mathrm{H} 2)$, it is anticipated that there is a negative relationship between POS and turnover intention. The two dimensions of POS found to have negative influence on turnover intention, namely POS1 $(\beta=-.525, \mathrm{p}<0.01)$ and POS2 $(\beta=-.181, \mathrm{p}<0.01)$. Thus, H2 is supported.

Table 2. POS and turnover intention

\begin{tabular}{llc}
\hline Dependent Variable & Independent Variable & $\begin{array}{c}\text { Std. Coefficient } \\
\text { Beta }(\beta)\end{array}$ \\
\hline Turnover Intention & Perceived organizational support 1 & $-0.525^{* *}$ \\
& Perceived organizational support 2 & $-0.181^{* *}$ \\
\hline & $\mathrm{R}^{2}$ & 0.33 \\
& Adjust $\mathrm{R}^{2}$ & 0.324 \\
& Sig. F & $63.204^{* *}$ \\
\hline
\end{tabular}

Note: Significant levels: $* * \mathrm{p}<0.01$

The relationship between Organizational Commitment and Turnover Intention - The third hypothesis (H3) examined whether there is a significant relationship between organizational commitment and turnover intention. Results indicated that $43.8 \%$ variances in turnover intention can be explained by PSS $\left(\mathrm{R}^{2}=43.8, \mathrm{p}<0.01\right)$. Third hypothesis (H3) predicted that there is a negative relationship between organizational commitment and turnover intention. The result indicated that two of the organizational commitment dimensions are found to have significant relationships with turnover intention, which are affective commitment $(\beta=-.221, \mathrm{p}<0.01)$ and normative commitment $(\beta=-.093$, $\mathrm{p}<0.01$ ). Thus, $\mathrm{H} 3 \mathrm{a}$ and $\mathrm{H} 3 \mathrm{~b}$ are supported. However, the third dimension continuance commitment did not show significant relationship with turnover intention $(\mathrm{p}>0.01)$. Therefore, H3c is not supported. Therefore it is concluded that $\mathrm{H} 3$ is supported. 
Table 3. Organizational commitment and turnover intention

\begin{tabular}{llc}
\hline Dependent Variable & Independent Variable & $\begin{array}{c}\text { Std. Coefficient Beta } \\
(\beta)\end{array}$ \\
\hline Turnover Intention & Affective commitment & $-0.221^{* *}$ \\
& Normative commitment & $-0.093^{* *}$ \\
& Continuance commitment & -0.070 \\
\hline & $\mathrm{R}^{2}$ & 0.438 \\
& Adjust $\mathrm{R}^{2}$ & 0.429 \\
& Sig. F & $49.621^{* *}$ \\
\hline
\end{tabular}

Note: Significant levels: $* * \mathrm{p}<0.01$

\section{Discussion and Conclusion}

The data analysis shows that all the hypotheses are accepted. Turnover intention has a significant relationship with POS, PSS and OC. The literature review earlier showed mixed findings concerning the relationship between POS, PSS, organizational commitment and turnover intention in the hospitality industry. However, the findings are consistent with previous studies showing that there is a significant and negative relationship between PSS and turnover intention (Maertz et al., 2007), POS and turnover intention (Talat Islam, 2013; Wayne et al., 1997) and organizational commitment on employees' turnover intention (Ben-Bakr et al., 1994). In line with the past research, the current study shows a negative and significant relationship between PSS and employees' turnover intention. PSS has become one of the important factors in predicting the turnover intention, the less support from supervisor, the more likely the employees would leave the organization (Maertz et al., 2007). Thus, the study has merely contributed to the ideas and reason of high turnover rate in the hotel organization.

Previous research has found out that POS influence employees' turnover intention negatively which in line with the current study. Employees respond the effect of POS by showing their loyalty and change their perceptions on turnover intention to stay longer with the organization (Talat Islam, 2013). Thus, if the hotel employees feel of being appreciate, cares on their well-being, cares for their satisfaction and shows more concern would reduce the turnover intention. Furthermore, three of the remaining factor which is the affective commitment, affective bonding commitment and normative commitment shows a significant and negative relationship towards employees' turnover. However, the continuance commitment shows no direct relationship with turnover intention which contradicts with previous studies by Tett and Meyer (1993), who found out that the organizational commitment, contributes exclusively towards turnover intentions. Affective commitment have a better prediction on turnover intention since the factor are considering the employees' emotional attachment with the organization whereas the continuance commitment only holds the perception of employees' in terms of their cost of living by staying with the organization.

There are several limitations observed in this research. The first limitation lies in the sample size which is relatively small. A total of 260 respondents participated in the survey using stratified and convenience sampling method targeted on three-star hotel employees. A larger sample would be able to provide a more precise, accurate and comprehensive results for the study. The second limitation refers to the study which limits its scope only on examining the effects of the PSS, POS and organizational commitment. For further research, other variables could also be included. The third limitation refers to the study performed on hospitality industry which focuses only in a specific location, Kota Kinabalu. The finding of this study cannot be generalized to other service industry and in different location since different industry and location have different perspective. The fourth limitation refers in this study mainly focus on hotel employees from middle management to below level management doubt on answering the questionnaires given which the questionnaires has been distributed by the human resource manager in every each of the three-star hotels. Some of the answer given by the hotel employees might not be sincere and truthful because the employees are concerned about the confidentiality of their responses which might reach the management. The fifth limitation in this study refers to the targeted hotels which are the three-star hotels only. Since three-star hotels are usually lacking in terms of facilities and benefits for its employees, it might influence the perception of the employees towards PSS and POS.

To conclude, the present study suggests that one of the ways to reduce the level of turnover intention among hotel employees is that the human resource managers should be more supportive, responsible, and able to strengthen the 
internal relationship among employees and management, care for the employees' well-being and understand the values of achieving the organization goals together. Therefore, there is a need to understand the important roles of each dimension of PSS, POS and organizational commitment i.e. affective commitment, continuance commitment and normative commitment in order to reduce employees' turnover intention in organizations.

\section{References}

Allen, N. J., \& Meyer, J. P. (1990). The measurement and antecedents of affective, continuance and normative commitment to the organization. Journal of Occupational Society, 63, 1-18. http://dx.doi.org/10.1111/j.2044-8325.1990.tb00506.x

Becker, T. E. (1992). Foci and bases of commitment: Are they distinctions worth making?. Academy of Management Journal, 35(1), 232-244. http://dx.doi.org/10.2307/256481

Ben-Bakr, K. A., Al-Shammari, I. S., Jefri, O. A., \& Prasad, J. N. (1994). Organizational commitment, satisfaction, and turnover in Saudi organizations: A predictive study. The Journal of Socio-Economics, 23(4), 449-456.

Cropanzano, R., Howes, J. C., Grandey, A. A., \& Toth, P. (1997). The relationship of organizational politics and support to work behaviors, attitudes, and stress. Journal of Organizational Behavior, 18, 159-180.

Davidson, M. C. G., Timo, N., \& Wang, Y. (2009). How much does labour turnover cost? A case study of Australian four- and five-star hotels. International Journal of Contemporary Hospitality Management, 22(4), 451-466. http://dx.doi.org/10.1108/09596111011042686

Dawley, D. D., Andrews, M. C., \& Bucklew, N. S. (2007). Mentoring, supervisor support, and perceived organizational support: What matters most?. Leadership and Organizational Development Journal, 29(3), 235-247. http://dx.doi.org/10.1108/01437730810861290

DeConinck, J. B., \& Johnson, J. T. (2009). The effects of perceived supervisor support, perceived organizational support, and organizational justice on turnover among salespeople. Journal of Personal Selling \& Sales Management, 29(4), 333-350. http://dx.doi.org/10.2753/PSS0885-3134290403

Dirks, K. T., \& Ferrin, D. L. (2002). Trust in leadership: Meta-analytic findings and implications for research and practice. Journal of Applied Psychology, 87(4), 611-628. http://dx.doi.org/10.1037/0021-9010.87.4.611

Eisenberger, R., Cummings, J., Armeli, S., \& Lynch, P. (1997). Perceived organizational support, discretionary treatment, and job satisfaction. Journal of Applied Psychology, 82(5), 812-820.

Eisenberger, R., Fasolo, P., \& Davis-LaMastro, V. (1990). Perceived organizational support and employee diligence, commitment, and innovation. Journal of Applied Psychology, 75(1), 51-59. http://dx.doi.org/10.1037/0021-9010.75.1.51

Eisenberger, R., Stinglhamber, F., Vandenberghe, C., Sucharski, I. L., \& Rhoades, L. (2002). Perceived supervisor support: Contributions to perceived organizational support and employee retention. Journal of Applied Psychology, 87(3), 565-573. http://dx.doi.org/10.1037/0021-9010.87.3.565

Fuller, J. B., Barnett, T., Hester, K., \& Relyea, C. (2003). A social identity perspective on the relationship between perceived organizational support and organizational commitment. The Journal of Social Psychology, 143(6), 789-791. http://dx.doi.org/10.1080/00224540309600432

Gentry, W. A., Kuhnert, K. W., Mondore, S. P., \& Page, E. E. (2006). The influence of supervisory-support climate and unemployment rate on part-time employee retention. Journal of Management Development, 26(10), 1005-1022. http://dx.doi.org/10.1108/02621710710833432

Griffeth, R. W., Hom, P. W., \& Gaertner, S. (2000). A meta-analysis of antecedents and correlates of employee turnover: Update, moderator tests, and research implications for the next millennium. Journal of Management, 26(3), 463-488. http://dx.doi.org/10.1177/014920630002600305

Huselid, M. A., \& Day, N. E. (1991). Organizational commitment, job involvement, and turnover: A substantive and methodological analysis. Journal of Applied Psychology, 76(3), 380-391.

Kanwar, Y. P. S., Singh, A. K., \& Kodwani, A. D. (2012). A study of job satisfaction, organizational commitment and turnover intent among the IT and ITES sector employees. Vision, 16(1), 27-35. http://dx.doi.org/10.1177/097226291201600103

Lashley, C. (2001). Costing staff turnover in hospitality service organizations. Journal of Services Research, 1(2), 3-24. 
Lee, C., \& Chon, K. (2000). An investigation of multicultural training practices in the restaurant industry: The training cycle approach. International Journal of Contemporary Hospitality Management, 12(2), 126-134. http://dx.doi.org/10.1108/09596110010309934

Maertz Jr, C. P., Griffeth, R. W., Campbell, N. S., \& Allen, D. G. (2007). The effects of perceived organizational support and perceived supervisor support on employee turnover. Journal of Organizational Behaviour, 28, 1059-1075. http://dx.doi.org/10.1002/job.472

Meyer, J. P., Allen, N. J., \& Smith, C. A. (1993). Commitment to organizations and occupations: Extension and test of a three-component conceptualization. Journal of Applied Psychology, 78(4), 538-551.

Mowday, R. T. (1998). Reflections on the study and relevance of organizational commitment. Human Resource Management Review, 8(4), 387-401. http://dx.doi.org/10.1016/S1053-4822(99)00006-6

Nasrin Arshadi. (2011). The relationships of perceived organizational support (POS) with organizational commitment, in-role performance, and turnover intention: Mediating role of felt obligation. Social and Behavioral Sciences, 30, 1103-1108. http://dx.doi.org/10.1016/j.sbspro.2011.10.215

Newman, A., Thanacoody, R., \& Hui, W. (2012). The effects of perceived organizational support, perceived supervisor support and intra-organizational network resources on turnover intentions: A study of Chinese employees in multinational enterprises. Personnel Review, 41(1), 56-72.

Porter, L. W., Steers, R. M., \& Mowday, R. T. (1974). Organizational commitment, job satisfaction, and turnover among psychiatric technicians. Journal of Applied Psychology, 59(5), 603-609. http://dx.doi.org/10.1037/h0037335

Reichers, A. E. (1985). A review and reconceptualization of organizational commitment. Academy of Management Review, 10(3), 465-476.

Rhoades, L., Eisenberger, R., \& Armeli, S. (2001). Affective commitment to the organization: The contribution of perceived organizational support. Journal of Applied Psychology, 86(5), 825-836.

Rhoades, L., \& Eisenberger, R. (2002). Perceived organizational support: A review of the literature. Journal of Applied Psychology, 87(4), 698-714. http://dx.doi.org/10.1037/0021-9010.87.4.698

Shanock, L. R., \& Eisenberger, R. (2006). When supervisors feel supported: Relationships with subordinates' perceived supervisor support, perceived organizational support, and performace. Journal of Applied Psychology, 91(3), 689-695. http://dx.doi.org/10.1037/0021-9010.91.3.689

Stinglhamber, F., \& Vandenberghe, C. (2003). Organizations and supervisors as sources of support and targets of commitment: A longitudinal study. Journal of Organizational Behavior, 24, 251-270.

Talat Islam, Saif Ur Rehman Khan, Ungku Norulkamar Ungku Bt Ahmad, \& Ishfaq Ahmed. (2013). Organizational learning culture and leader-member exchange quality: The way to enhance organizational commitment and reduce turnover intentions. The Learning Organization, 20(4/5), 322-337.

Talat Islam, Saif Ur Rehman Khan, Ungku Norulkamar Bt Ungku Ahmad, Ghulam Ali, Ishfaq Ahmed, \& Zulfqar Ahmad Bowra. (2013). Turnover intentions: The influence of perceived organizational support and organizational commitment. Social and Behavioral Sciences, 103, 1238-1242.

Tett, R. P., \& Meyer, J. P. (1993). Job satisfaction, organizational commitment, turnover intention, and turnover: Path analyses based on meta-analytic findings. Personnel Psychology, 46, 259-293. http://dx.doi.org/10.1111/j.1744-6570.1993.tb00874.x

Tuzun, I. K., \& Kalemci, R. A. (2011). Organizational and supervisory support in relation to employee turnover intentions. Journal of Managerial Psychology, 27(5), 518-534. http://dx.doi.org/10.1108/02683941211235418

Wayne, S. J., Shore, L. M., Bommer, W. H., \& Tetrick, L. E. (2002). The role of fair treatment and rewards in perceptions of organizational support and leader-member exchange. Journal of Applied Psychology, 87(3), 590-598. http://dx.doi.org/10.1037/0021-9010.87.3.590

Wayne, S. J., Shore, L. M., \& Liden, R. C. (1997). Perceived organizational support and leader-member exchange: A social exchange perspective. Academy of Management Journal, 40(1), 82-111. http://dx.doi.org/10.2307/257021

Wong, Y., Ngo, H., \& Wong, C. (2002). Affective organizational commitment of workers in Chinese joint ventures. Journal of Managerial Psychology, 17(7), 580-598. http://dx.doi.org/10.1108/02683940210444049 